\title{
Evaluating the Financial Impact of Branding Using Trademarks: A Framework and Empirical Evidence
}

Firms spend considerable efforts to build brand awareness and associations among consumers. Yet there is a limited understanding of the financial returns of such investments. In this article, the authors present a framework that uses trademarks as measures of firms' branding efforts. They classify trademarks into two categories-brandidentification trademarks and brand-association trademarks-and propose that they are indicators of firm efforts to build brand awareness and associations among consumers, respectively. The authors then evaluate the chain of effects linking such assets with metrics of firms' financial value. A longitudinal analysis of data collected from secondary sources reveals that the stock (i.e., total number) of brand-association trademarks available to firms in time period $t$ increases their cash flow, Tobin's q, return on assets, and stock returns and reduces their cash-flow variability in period $t+1$. Furthermore, the authors observe that the stock of brand-identification trademarks owned by firms in period $t-1$ influences the effects of brand-association trademarks on cash flow, Tobin's q, and stock returns. Together, these findings provide useful insights into the financial value of branding.

Keywords: branding, trademarks, brand awareness, brand associations, financial performance, random-coefficients model, growth model

$\mathbf{M}$ arketing managers spend a considerable portion of their budgets to build and manage brand equity (Madden, Fehle, and Fournier 2006). However, they face increasing pressures to justify the financial returns on such expenses (Srivastava, Shervani, and Fahey 1999). Consequently, brand valuation has taken a central role in both academic research and practitioner research (Salinas and Ambler 2008), with researchers and managers alike stressing continuing investigations in this area (Marketing Science Institute-Emory Marketing Institute 2007).

Among the many issues studied, researchers have emphasized the importance of linking the consumer-based and financial-market-focused perspectives on brand equity (Keller and Lehmann 2006). The consumer-based view emphasizes efforts that build brand awareness and associations among consumers to enhance brand equity (e.g., Keller 1993). In contrast, the financial-market perspective

Alexander Krasnikov is Assistant Professor of Marketing, School of Business, George Washington University (e-mail: avkrasn@gwu.edu). Saurabh Mishra is Assistant Professor of Marketing, Desautels Faculty of Management, McGill University (e-mail: saurabh.mishra@mcgill.ca). David Orozco is Assistant Professor of Business Law, School of Business and Economics, Michigan Technological University (e-mail: dorozco@mtu. edu). The authors acknowledge the financial assistance provided by the Marketing Science Institute and the Emory Marketing Institute to conduct this research. The study was motivated by discussions with faculty members at the Kellogg School of Management's Center for Research in Technology and Innovation. The authors also thank the three anonymous JM reviewers and the special issue editor Rajendra K. Srivastava for their valuable comments. The authors contributed equally to the article and are listed alphabetically. focuses on the financial outcomes of brand equity, such as shareholder value (e.g., Kerin and Sethuraman 1998). However, because measures that capture consumer brand awareness and associations are often difficult to link with financial-market outcomes (Ailawadi, Lehmann, and Neslin 2003), there have been limited efforts to link the two perspectives.

Some researchers have attempted to bridge the two views (e.g., Mizik and Jacobson 2008; Shankar, Azar, and Fuller 2008). The focus of such studies, however, has primarily been on finding the financial value of consumer brand associations, with limited attention devoted to understanding the role of brand awareness. Consumers' brand awareness is an important dimension of brand equity (Keller 1993) and is a prerequisite for building brand associations (Krishnan 1996). Consequently, mere valuation of brand associations may be insufficient. Rather, an investigation into the following question becomes important: What are the financial returns to firms from building brand awareness and associations among consumers?

We attend to this question in this research. Specifically, we present a framework that builds on the close relationship between brands and trademarks (Aaker 1991; Cohen 1986) to argue that firms' trademark activities capture a significant portion of their branding efforts. We classify trademarks into two broad categories-brand-identification trademarks and brand-association trademarks - and propose that they are indicators of firms' efforts to build brand awareness and associations, respectively, among consumers. We then evaluate the links of these two types of trademarks with multiple metrics of firms' financial performance. 
Our analysis confirms that both brand-identification and brand-association trademarks affect firms' financial value. In particular, the stock (i.e., total number) of brandassociation trademarks that firms own in time period $t$ are observed to increase their cash flows, Tobin's q, return on assets (ROA), and stock returns and to reduce their cash flow variability in period $t+1$. Furthermore, we observe that the stock of brand-identification trademarks owned by firms in period $\mathrm{t}-1$ influences the effects of brandassociation trademarks on cash flow, Tobin's q, and stock returns.

Together, our findings provide useful insights into the financial value of branding and result in multiple theoretical and managerial contributions. First, we provide a comprehensive understanding of the chain of effects that links firms' efforts to build consumer brand awareness and associations with their financial performance. Second, by using trademarks in brand-valuation research, we encourage marketing scholars to focus more on these objective and easily accessible assets in their research. Last, many firms report that managers pay inadequate attention to trademarks (Bosworth 2003). Our findings should encourage managers to focus more on their firms' trademark activities. Next, we present our conceptual framework, discuss our methodology and results, and close with implications and limitations of this research.

\section{Conceptual Framework}

\section{Brand Equity and Its Dimensions}

Brand equity has been defined from multiple perspectives in the extant literature (Keller and Lehmann 2006). In this research, we follow the consumer-based perspective, which defines brand equity as "the differential effect that brand knowledge has on consumer response to the marketing of that brand" (Keller 1993, p. 2). To understand how consumers store and access brand knowledge, researchers have built on extant memory frameworks laid out in the psychology literature (e.g., Wyer and Srull 1989).

With respect to brand knowledge, these frameworks imply that the brand name or identifier is a central concept (Nedungadi 1990), which, when developed in memory, helps consumers recall important attribute and nonattribute associations they attach to the brand (Krishnan 1996). Attribute-based associations are the links that consumers hold between brands and product characteristics (or attributes), such as unique product color, scent, package, shape, and sound (e.g., Srinivasan, Park, and Chang 2005). Nonattribute-based associations include consumer perceptions of brand-use imagery or brand personality (Mizik and Jacobson 2008).

The previously mentioned frameworks suggest that brand equity, as represented in consumers' memory, has two dimensions-namely, brand awareness and brand associations, with brand awareness being a necessary precondition for the creation of strong brand associations (Keller 1993). Trademarks capture a significant portion of firms' efforts to build brand awareness and associations among consumers. We explain this argument in more detail next.

\section{Trademarks: Definition, Types, and Link with Brand Equity}

The U.S. federal law (Lanham Act, 15 U.S.C. § 1127 [1982]) defines trademark as "any word, name, symbol or device, or combination thereof, adopted and used by a manufacturer or merchant to identify his goods and distinguish them from those manufactured or sold by others." This definition parallels that of brand, which has been defined as "[a] name, term, design, symbol, or any other feature that identifies one seller's good or service as distinct from those of other sellers" (Bennett 1995, p. 27), thus implying the close relationship between trademarks and brands.

Although trademarks have been recognized under U.S. law for a long time, the federal Trademark Act of 1946, commonly known as the Lanham Act, provides important guidelines for their precise definition and eligibility requirements (Oathout 1981). Under the Lanham Act, to register trademarks with the U.S. Patent and Trademark Office (PTO), the onus lies on the registrant firm to prove (1) that its trademarks are unique and/or (2) that consumers readily identify them with the firm (Melton 1979). Firms often establish these conditions in courts by documenting advertising and promotional spending that links their brands with trademarks, by providing survey reports of consumers' mental representations of their trademarks, or by presenting expert testimony (Jacoby 2001). These requirements ensure that a firm's trademarks are uniquely and strongly linked with its brands in the minds of consumers, thus lending support to our thesis that trademarks are a measure of a firm's consumer-focused branding efforts.

Furthermore, the legal criteria set by the Lanham Act and numerous subsequent court decisions have led to the registrations of various trademarks, which can be classified into two broad categories that parallel the brand-awareness and brand-association dimensions of brand equity discussed previously (see also the Appendix). The first category comprises trademarks that are related to brand names (e.g., Nike), brand logos or brand symbols (e.g., Nike's swoosh), or a combination of the two. Because such trademarks represent brand identifiers, they capture a significant portion of firms' efforts to build brand awareness among consumers. We refer to names, logos, and symbols as brandidentification trademarks in this research.

The second category of trademarks encompasses the different attribute and nonattribute associations that consumers attach to brands. Trademarks that capture attribute and nonattribute associations can be decorative or informational (U.S. Trademark Manual of Examination Procedures $\S \S 1202.03-1202.04)$. Decorative trademarks extend to design elements (e.g., color, motion, packaging, scent, shape), whereas informational trademarks include slogans (e.g., Nike's "Just Do It"), which may communicate imagerelated messages that complement the brand (Jacoby 2001). Together, this category of brand-association trademarks reflects a significant portion of a firm's efforts to develop consumer brand associations. ${ }^{1}$ We subsequently describe

${ }^{1}$ Certain aspects of a firm's branding strategy affect consumer brand associations but cannot be protected through trademarks. 
how the two types of trademarks, given their close relationship to consumer brand awareness and associations, may influence firm value.

\section{Brand Equity, Trademarks, and Firm Value}

Industry experts often suggest that trademarks are important intellectual property assets that enhance shareholder value (e.g., Davidson 2004). Several observations of industry practice also support this view. For example, in 2007, the retail company Sears Holding Corp. transferred some of the brand equity residing in its trademarks to a wholly owned legal vehicle to issue $\$ 1.8$ billion in securities (BusinessWeek 2007).

In examining the source of this value, we direct our attention to the two types of trademarks discussed previously. With respect to brand-identification trademarks, such as brand names, logos, and symbols, extant literature points to at least two characteristics that attest to their value potential. First, such trademarks enable consumer recognition of brands in the crowded marketplace (Henderson and Cote 1998). Second, brand identifiers also often serve as important predictive cues of product performance to consumers (Erdem and Swait 1998). Therefore, we can expect that a strong regime of brand-identification trademarks positively affects consumer preference for the brand.

Beyond brand-identification trademarks, brandassociation trademarks may provide significant value to firms. Brand associations, as reflected in such trademarks, have been argued to positively affect consumers' brandrelated attitudes (Keller 1993). Furthermore, a more complex network of associations has been shown to give consumers greater confidence in their attitudes (Pullig, Netemeyer, and Biswas 2006), which makes them less prone to attitude change (Pham and Muthukrishnan 2002) and helps attenuate the effect of competitors' persuasion attempts (Pechmann and Ratneshwar 1991). In addition, firms may leverage consumer brand associations to introduce brand extensions, which can help firms enter new, often more profitable product markets (e.g., Dacin and Smith 1994).

Furthermore, there is evidence that a firm's efforts to build strong brand equity that is secured against dilution through trademarks have a positive impact on its financial value. Prior research has suggested that strong brand equity helps firms generate higher revenue premiums, reduce vulnerability to competitive actions, increase long-term effectiveness of promotions, and lower promotional expenditures for subsequent brand extensions (e.g., Ailawadi, Lehmann, and Neslin 2003; Slotegraaf and Pauwels 2008; Srinivasan, Park, and Chang 2005), all of which positively influence firms' financial value (Mizik and Jacobson 2008). Indeed, researchers have emphasized the importance of trademarks in protecting this value by drawing attention to the threats to

Nevertheless, we believe that trademark registration activities reflect a significant portion of firms' efforts to create brand associations among consumers. We thank an anonymous reviewer for this comment. brand equity from counterfeiting or trademark infringement (e.g., Morrin, Lee, and Allenby 2006).

Finally, trademark value can also be inferred from the manner in which firms often leverage trademarks through licensing (Jacoby 2001). Licensing involves a firm granting permission to a third party (i.e., a licensee) to use the firm's trademarks in association with the licensee's products and services in exchange for royalties. For example, the leading pharmaceutical firm AstraZeneca licensed the trademark for its Prilosec heartburn medication and the color purple associated with the product to Procter \& Gamble (P\&G), which launched it as an over-the-counter medicine (U.S. Trademark Registration No. 2806099).

In summary, we expect that both brand-identification and brand-association trademarks are linked with firm financial value. Furthermore, with respect to formulating the chain of effects that links these two types of trademarks with financial performance, extant consumer-based brand equity frameworks (e.g., Keller 1993; Krishnan 1996) indicate that the stock of brand-identification trademarks a firm owns provides a base (or a precondition) on which the firm can build a strong regime of brand-association trademarks to enhance its financial value.

\section{Methodology}

\section{Database Overview}

To evaluate our conceptual model, we compiled a data set by integrating information from several secondary sources, including Standard \& Poor's COMPUSTAT database, the University of Chicago's Center for Research in Security Prices (CRSP), the PTO's Trademark Electronic Search System (TESS), and firms' annual reports.

The firms in the final sample were from the following industries: beverages, apparel, computer and communication equipment, confectionary, department stores, eating places, grocery stores, home appliances, jewelry, motor vehicles, packaged food, perfumes and cosmetics, software, and wine and malt beverages. We focused on multiple industries to enhance the generalizability of our findings. From these industries, we selected firms for which information required for the analysis was available in the COMPUSTAT and CRSP databases for the period 1995-2005.

We focused on the 1995-2005 period for two reasons. First, a longitudinal assessment helps increase the robustness of our findings and is in line with previous marketing research on brand valuation (e.g., Bahadir, Bharadwaj, and Srivastava 2008; Rao, Agarwal, and Dahlhoff 2004). Second, and more important, several important legal developments in the early 1990s (e.g., the 1989 Trademark Revision Act, the 1992 U.S. Supreme Court ruling on nontraditional trademarks) increased the legal certainty of certain trademarks such as sound, scent, shape, and motion marks. Such trademarks enable firms to establish and protect important aspects of attribute-based consumer brand associations. Consequently, an accurate measurement of brand-association trademarks, one of our key independent variables, necessitated the inclusion of these trademarks in our analysis. Our assessment of trademark registrations by firms in our sample confirmed that the period following 
1995 most accurately captured sound, scent, shape, and motion trademarks in the data set.

Overall, the foregoing criteria resulted in a sample of 108 firms, with an approximately 50-50 split of manufacturing and service firms. In the following sections, we explain our measures in detail.

\section{Measures}

Financial performance. To evaluate the financial value of branding efforts, we focused on multiple measures of firms' financial performance. First, we included cash flow and cash flow variability as the main dependent variables of interest in this research. Economic theory posits that a firm's ability to generate future cash flows determines the firm's value (Rappaport 1986). Indeed, given the importance of cash flow to firms, a significant volume of research has emerged on this topic in the fields of finance and accounting (e.g., Dechow, Kothari, and Watts 1998; Ismail and Choi 1996). In the marketing literature, Gruca and Rego (2005) document the importance of cash flows as measures of financial performance and provide guidelines to capture these metrics. We followed their approach in calculating cash flow levels and variability in this research, using information collected from COMPUSTAT.

Second, although we focused on cash flow and cash flow variability, we recognize that there are alternative measures of shareholder value. Therefore, to enhance the validity of our findings, we also included Tobin's q, ROA, and stock returns as additional measures of financial value.

Tobin's q, the ratio of a firm's market value to the replacement cost of its assets, is a forward-looking measure that summarizes investors' expectations regarding a firm's potential to generate future revenues (Lindenberg and Ross 1981). Previous research in brand valuation has also used Tobin's q to evaluate the financial value of different branding strategies (e.g., Rao, Agarwal, and Dahlhoff 2004). We calculated Tobin's q using the methodology that Chung and Pruitt (1994) outline, with information collected from COMPUSTAT and CRSP.

In addition to Tobin's q, extant research on financial statement analysis (e.g., Fairfield, Sweeney, and Yohn 1996) implies that financial ratios, such as ROA, provide information about future profitability to investors. Therefore, we also included ROA as a measure of financial performance, using information obtained from COMPUSTAT.

Finally, we evaluated stock returns as an additional measure of financial value. Researchers in marketing have increasingly adopted this forward-looking measure to evaluate the value relevance of marketing activities and consumer brand perceptions (Luo 2009; Mizik and Jacobson 2008). For our analysis, we used the Fama and French (1993) momentum multirisk market model to measure stock returns. Specifically, we calculated the monthly stock returns for firm $\mathrm{i}$ in industry $\mathrm{j}$ and month $\mathrm{k}\left(\mathrm{ST}_{\mathrm{ijk}}\right)$ using Equation 1:

(1) $\mathrm{ST}_{\mathrm{ijk}}=\chi_{0}+\chi_{1} \times \mathrm{RM} \_\mathrm{RF}_{\mathrm{k}}+\chi_{2} \times \mathrm{HML}_{\mathrm{k}}+\chi_{3} \times \mathrm{SMB}_{\mathrm{k}}$

$$
+\chi_{4} \times \mathrm{UMD}_{\mathrm{k}}+\omega_{\mathrm{ijk}},
$$

where

$$
\begin{aligned}
\mathrm{ST}_{\mathrm{ijk}}= & \text { the difference between stock return for firm } \\
& \mathrm{i} \text { in industry } \mathrm{j} \text { and month } \mathrm{k} \text { and the return on } \\
& \text { T-bills in } \mathrm{k}, \\
\mathrm{RM}_{-} \mathrm{RF}_{\mathrm{k}}= & \text { the value-weighted return on all stocks } \\
& \text { listed in the New York Stock Exchange, } \\
& \text { American Stock Exchange, and NASDAQ } \\
& \text { less the one-month T-bill rate in month } \mathrm{k}, \\
\mathrm{HML}_{\mathrm{k}}= & \text { the book-to-market factor adjusted for } \\
& \text { growth in month } \mathrm{k}, \\
\mathrm{SMB}_{\mathrm{k}}= & \text { the size-based risk factor in month } \mathrm{k}, \\
\mathrm{UMD}_{\mathrm{k}}= & \text { the monthly momentum factor (up minus } \\
& \text { down) in month } \mathrm{k}, \text { and } \\
\omega_{\mathrm{ijk}}= & \text { residuals for firm } \mathrm{i} \text { in industry } \mathrm{j} \text { and month } \\
& \mathrm{k} .^{2}
\end{aligned}
$$

Moreover, as Luo (2009) suggests, we corrected for serial correlations by regressing $\omega_{\mathrm{ijk}}$ on its lagged value and by using the predicted value $\left(\bar{\omega}_{\mathrm{ijk}}\right)$ as the measure of stock returns. Then, following Mizik and Jacobson (2008), we aggregated the monthly stock return data to annual for firm $\mathrm{i}$ in industry $\mathrm{j}$ and year $\mathrm{t}\left(\mathrm{RST}_{\mathrm{ijj}}\right)$ using Equation 2:

$$
\operatorname{RST}_{\mathrm{ijt}}=\log \left[\prod_{\mathrm{k}=1}^{12}\left(1+\varpi_{\mathrm{ijk}}\right)\right] .
$$

As a result, we obtained 924 annual stock return values for 89 firms in our sample.

Trademark-based measures of brand awareness and brand associations. We extracted detailed information on all trademarks registered by the 108 firms in our sample from the PTO TESS database up to the year 2005. During this process, we retrieved the following information for each trademark: serial number, registration number, year of registration, owner name, trademark description, trademark drawing codes, and status (live or canceled). While retrieving the trademark data, two authors with the help of two research assistants manually verified that the trademarks corresponded to the firm in question. Overall, we identified 22,060 live and registered trademarks. Two independent coders then coded the trademarks as either brandidentification or brand-association trademarks. A detailed coding plan was developed to assist the coders. The plan included the definition and examples of the two categories of trademarks (examples were the same as those given in the Appendix) and a coding nomenclature.

In developing our coding plan, we followed the classifications discussed previously. Trademarks that included brand names and/or symbols in the description field were coded as brand-identification trademarks. Furthermore, the coders identified trademarks specifying brand attribute or image as brand-association trademarks. For example, they coded Target Corp.'s trademark Archer Farms as a brand identifier but coded its slogan "Expect more. Pay less." as a

${ }^{2}$ Fama-French factors were downloaded from http://mba.tuck. dartmouth.edu/pages/faculty/ken.french/index.html. 
nonattribute trademark within the category of brandassociation trademarks. Similarly, they coded Apple's iPod shape trademark as an attribute-based trademark, also in the category of brand-association trademarks.

Through this process, we identified 4146 brandassociation trademarks and 17,914 brand-identification trademarks. Initial coder agreement was high (89\%), and the coders resolved their differences to produce a final set of codes. Furthermore, to verify consistency of our trademark classification plan with experts in trademark law, we contacted a large midwestern law firm through a survey. Thirty lawyers completed and returned the survey. ${ }^{3}$ Their overall agreement with our coding scheme was high (88\%).

Finally, we verified the coding of a subset of trademarks with the classification plan used by the PTO. For motion, sound, scent, or shape trademark registrations, the PTO assigns a specific drawing code. We extracted all trademarks with this drawing code and evaluated their correspondence with our coding. We identified no discrepancies with our classification. Together, these steps gave us confidence that our measures adequately captured the branding efforts of firms in our sample. In the final analysis, we used the stock of all live brand-association and brandidentification trademarks available to a firm in a given year (e.g., 1995) as our measures.

Controls. In addition, following the work of Gruca and Rego (2005), we included several firm- and industryspecific controls in our analysis. We outline these in detail in the next section. Tables 1 and 2 present details on the variables.

\section{Model Formulation}

Both conceptual and empirical considerations shaped our model formulation. First, our conceptual framework suggested that investments in building a strong network of brand associations increase a firm's financial performance. This is in line with previous research in marketing that has established that certain types of brand associations enhance shareholder value (e.g., Mizik and Jacobson 2008). In our model, we accounted for this relationship by introducing a main effect of brand associations on the outcome variables. However, we also posited that research in consumer behavior suggests that the effectiveness of brand associations depends on consumers' brand awareness (Krishnan 1996). We accounted for this relationship by incorporating an interaction between brand-identification trademarks and brand-association trademarks on firm performance in our model.

Second, our sample design also determined our modeling approach. We used a cross-sectional and longitudinal panel sample with multiple levels of observations (by firm,

\footnotetext{
${ }^{3}$ On average, respondents were familiar with trademark laws (reporting an average of 5.43 on a seven-point scale measuring "How familiar are you with trademark laws?") and had an average legal experience of 15.1 years.
}

industry, and period). Therefore, we used a growth model, a special case of random coefficients models, to estimate the impact of the two types of trademarks on firms' value. Such an approach is relevant for multilevel data and helps both model different sources of observed heterogeneity, which is common in nested designs, and account for any unobserved firm- and industry-specific effects (Bryk and Raudenbush 1992).

We modeled variation in the financial outcome variable Ind $_{\text {ijt }}$ (i.e., cash flow, cash flow variability, Tobin's q, ROA, and stock returns) for firm $\mathrm{i}$ in industry $\mathrm{j}$ in period $\mathrm{t}$ as a function of lagged earnings $\left(\operatorname{Earn}_{\mathrm{ijt}-1}\right)$ and the stock of all live brand-association trademarks $\left(\mathrm{BrA}_{\mathrm{ijt}-1}\right)$ in period $\mathrm{t}-1$ :

(3) $\quad \operatorname{Ind}_{\mathrm{ijt}}=\beta_{0 \mathrm{ij}}+\beta_{1 \mathrm{ij}} \times \mathrm{BrA}_{\mathrm{ijt}-1}+\beta_{2 \mathrm{ij}} \times \mathrm{EARN}_{\mathrm{ijt}-1}+\varepsilon_{\mathrm{ijt}}$.

Furthermore, it is possible that there is heterogeneity related to firm-level characteristics. Consequently, in Equation 4, we modeled the variation in intercept and slopes as follows:

$$
\begin{aligned}
\beta_{0 \mathrm{ij}}= & \gamma_{00 \mathrm{j}}+\gamma_{01 \mathrm{j}} \times \mathrm{SIZE}_{\mathrm{ij}}+\gamma_{02 \mathrm{j}} \times \mathrm{RD}_{\mathrm{ij}}+\gamma_{03 \mathrm{j}} \times \mathrm{AD}_{\mathrm{ij}} \\
& +\gamma_{04 \mathrm{j}} \times \mathrm{TM}_{\mathrm{ij}}+\eta_{0 \mathrm{ij}}, \\
\beta_{1 \mathrm{ij}}= & \gamma_{10 \mathrm{j}}+\gamma_{11 \mathrm{j}} \times \mathrm{BrAw}_{\mathrm{ijt}-2}+\eta_{1 \mathrm{ij}}, \text { and } \\
\beta_{2 \mathrm{ij}}= & \gamma_{20 \mathrm{j}}+\eta_{2 \mathrm{ij}},
\end{aligned}
$$

where

SIZE $_{\mathrm{ij}}=$ size of firm $\mathrm{i}$ in industry $\mathrm{j}$,

$\mathrm{RD}_{\mathrm{ij}}=$ research and development intensity of firm $\mathrm{i}$ in industry $\mathrm{j}$,

$\mathrm{AD}_{\mathrm{ij}}=$ advertising intensity of firm $\mathrm{i}$ in industry $\mathrm{j}$, and

$\mathrm{TM}_{\mathrm{ij}}=$ trademark intensity of firm $\mathrm{i}$ in industry $\mathrm{j}$.

The normally distributed error terms $\eta_{0 \mathrm{ij}}, \eta_{1 \mathrm{ij}}$, and $\eta_{2 \mathrm{ij}}$ captured unobserved effects specific to firm $\mathrm{i}$ in industry $\mathrm{j}$. Because we observed that advertising, research and development, and trademark intensities did not vary much during the 11-year time frame covered in our research, we averaged the values for each firm. We then specified the estimation for capturing the variation in slope for $\mathrm{BrA}_{\mathrm{ijt}-1}\left(\beta_{1 \mathrm{ij}}\right)$. Previously, we posited that brand associations are built on a firm's prior efforts to build brand awareness among consumers. As such, we expected that the variation in the impact of brand-association trademarks in period $\mathrm{t}-1$ $\left(\mathrm{BrA}_{\mathrm{ijt}-1}\right)$ on financial performance and shareholder value in period $\mathrm{t}$ would be contingent on the stock of brandidentification trademarks available in period $\mathrm{t}-2\left(\mathrm{BrAw}_{\mathrm{ijt}-2}\right)$. To incorporate this interaction, we adopted recommendations for conducting moderation analysis in random coefficients models (Hofmann and Gavin 1998) and performed within-firm centering of our Level 1 variables in Equation 3 $\left(\right.$ BrA $_{\mathrm{ijt}-1}$ and $\left.\operatorname{Earn}_{\mathrm{ijt}-1}\right)$.

Furthermore, because our sample draws from multiple industries, there may be heterogeneity in parameter estimates in Equation 4 as a result of industry effects. Therefore, in Level 3 (Equation 5), we modeled the variation in firm-level effects $\left(\gamma_{00 \mathrm{j}}, \gamma_{10 \mathrm{j}}\right.$, and $\left.\gamma_{20 \mathrm{j}}\right)$ using industry-level variables. The terms $\xi_{00 \mathrm{j}}, \xi_{10 \mathrm{j}}$, and $\xi_{20 \mathrm{j}}$ are normally distributed and account for unobserved effects that are specific to industry $\mathrm{j}$. 
TABLE 1

Description of Variables

\begin{tabular}{|c|c|c|}
\hline Variable & Description & Source \\
\hline Cash flows (CF) & Cash flows from operations (in millions of dollars) & COMPUSTAT \\
\hline $\begin{array}{l}\text { Cash flow variability } \\
\text { (CFV) }\end{array}$ & $\begin{array}{l}\text { Ratio of firm's quarterly cash flow coefficient of variation (standard } \\
\text { deviation divided by mean for a given year) to market's quarterly cash flow } \\
\text { coefficient of variation }\end{array}$ & COMPUSTAT \\
\hline Tobin’s q (Q) & $\begin{array}{l}\text { The following ratio: [(number of common shares outstanding } \times \text { share } \\
\text { price }+ \text { liquidating value of preferred stock }+ \text { book value of long-term debt }+ \\
\text { short-term liabilities }- \text { short-term assets)/(book value of total assets)] }\end{array}$ & $\begin{array}{l}\text { COMPUSTAT and } \\
\text { CRSP }\end{array}$ \\
\hline ROA & Ratio of net income before extraordinary items to total assets & COMPUSTAT \\
\hline Stock returns (RST) & $\begin{array}{l}\text { Abnormal stock price fluctuations after controlling for the average market } \\
\text { portfolio returns in three stock exchanges }\end{array}$ & $\begin{array}{l}\text { CRSP and French's } \\
\text { database }\end{array}$ \\
\hline Earnings (EARN) & Net income before extraordinary items (in millions of dollars) & COMPUSTAT \\
\hline $\begin{array}{l}\text { Advertising intensity } \\
\text { (AD) }\end{array}$ & $\begin{array}{l}\text { Ratio of firm's annual advertising expenditures to total assets divided by the } \\
\text { industry's average ratio of advertising expenditures to total assets }\end{array}$ & COMPUSTAT \\
\hline$R \& D$ intensity $(R D)$ & $\begin{array}{l}\text { Ratio of firm's R\&D expenditures to total assets divided by the industry's } \\
\text { average ratio of } R \& D \text { expenditures to total assets }\end{array}$ & COMPUSTAT \\
\hline Size (SIZE) & Logarithm of total number of firm employees & COMPUSTAT \\
\hline Demand (DMND) & Average five-year sales growth for industry & COMPUSTAT \\
\hline $\begin{array}{l}\text { Demand instability } \\
\text { (INST) }\end{array}$ & Standard deviation of five-year sales growth for industry & COMPUSTAT \\
\hline $\begin{array}{l}\text { Market concentration } \\
(\mathrm{HHI})\end{array}$ & $\begin{array}{l}\text { Herfindahl concentration index ( } \mathrm{HHI} \text { ) (i.e., sum of squared shares of firms } \\
\text { in the industry) }\end{array}$ & COMPUSTAT \\
\hline Industry type (SERV) & Dummy for service (1) versus manufacturing (0) firm & \\
\hline $\begin{array}{l}\text { Brand-identification } \\
\text { trademarks (BrAw) }\end{array}$ & $\begin{array}{c}\text { Stock of all live brand-identification trademarks a firm owned in a given } \\
\text { year }\end{array}$ & PTO TESS \\
\hline $\begin{array}{l}\text { Brand-association } \\
\text { trademarks }(\mathrm{BrA})\end{array}$ & Stock of all live brand-association trademarks a firm owned in a given year & PTO TESS \\
\hline $\begin{array}{l}\text { Trademark intensity } \\
\text { (TM) }\end{array}$ & $\begin{array}{l}\text { Ratio of firm trademark registrations to total number of trademark } \\
\text { registrations in the industry in a given period }\end{array}$ & PTO TESS \\
\hline
\end{tabular}

Notes: $R \& D$ = research and development.

(5) $\gamma_{00 \mathrm{j}}=\alpha_{001} \times \mathrm{DMND}_{\mathrm{jt}}+\alpha_{002} \times \mathrm{INST}_{\mathrm{jt}}+\alpha_{003} \times \mathrm{HHI}_{\mathrm{jt}}$ $+\alpha_{004} \times \mathrm{SERV}_{\mathrm{j}}+\xi_{00 \mathrm{j}}$

$\gamma_{10 \mathrm{j}}=\alpha_{100}+\xi_{10 \mathrm{j}}$, and

$\gamma_{20 \mathrm{j}}=\alpha_{200}+\xi_{20 \mathrm{j}}$

where

$\mathrm{DMND}_{\mathrm{jt}}=$ overall demand in industry $\mathrm{j}$ in period $\mathrm{t}$,

$\mathrm{INST}_{\mathrm{jt}}=$ demand instability in industry $\mathrm{j}$ in period $\mathrm{t}$,

$\mathrm{HHI}_{\mathrm{jt}}=$ market concentration ratio in industry $\mathrm{j}$ in period $\mathrm{t}$, and

$\mathrm{SERV}_{\mathrm{j}}=$ indicator for service (1) versus manufacturing (0) for industry $\mathrm{j}$.
Finally, we applied an autoregressive structure to the residuals in the growth model to account for autocorrelation in our data. 4 We also conducted White's test to ensure that residuals are homoskedastic for all outcome variables.

\section{Results}

To estimate the growth model (Equations 3-5), we used a stepwise approach and modeled different sources of variation (i.e., within firm, industries, and over time) (Bryk and

\footnotetext{
${ }^{4}$ We conducted a pooled Durbin-Wood test and found evidence for autocorrelation in our data.
} 
TABLE 2

Descriptive Statistics

$\begin{array}{lllll}M & \text { SD } & \text { N } & \text { CF } & \text { CFV }\end{array}$

Q ROA

RST BrA BrAw EARN SIZE

AD RD

TM DMND INST

Cash flows (CF)

$2029.477 \quad 3692.820 \quad 1154 \quad 1.000$

Cash flow variability (CFV)

Tobin's q (Q)

ROA

Stock returns (RST)

Brand association (BrA)

Brand awareness (BrAw)

Earnings (EARN)

Size (SIZE)

Advertising intensity (AD)

$\mathrm{RD}$ intensity (RD)

Trademark intensity (TM)

Demand (DMND)

$\begin{array}{lllll}.605 & 3.531 & 1134 & .039 & 1.000\end{array}$

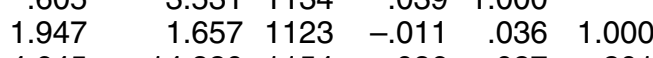

$\begin{array}{lllllll}4.645 & 14.820 & 1154 & .086 & .027 & .201 & 1.000\end{array}$

$\begin{array}{llllllll}-.008 & .129 & 969 & .049 & .033 & -.045 & .056 & 1.000\end{array}$

$\begin{array}{lllllllll}2.641 & 5.007 & 1188 & .257 & -.056 & .068 & .068 & .027 & 1.000\end{array}$

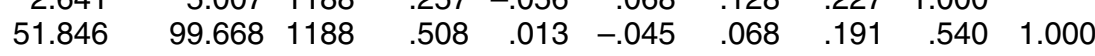

$\begin{array}{lllllllllll}1051.712 & 2589.619 & 1163 & .843 & .041 & .009 & .105 & .077 & .288 & .494 & 1.000\end{array}$

$\begin{array}{rrrrrrrrrrrr}3.120 & 1.603 & 108 & .512 & .051 & -.095 & .217 & .012 & .276 & .367 & .386 & 1.000\end{array}$

Instability (INST)

1.161
1.140

.600108

$\begin{array}{rrrrrrrrr}.512 & .051 & -.095 & .217 & .012 & .276 & .367 & .386 & 1.000 \\ -.020 & -.028 & -.057 & -.177 & -.007 & -.044 & -.071 & -.006 & -.226\end{array}$

.169

2.075108

$-.085 \quad .026$

$\begin{array}{rrrr}.097 & -.177 & -.007 & -.04 \\ .006 & -.003 & .003 & .02 \\ .182 & -.017\end{array}$

$\begin{array}{lllll}.044 & -.071 & -.006 & -.226 & 1.000\end{array}$

093

.207108

$.267-.030$

$.084 \quad 154-.006-.022$

$\begin{array}{llllllllll}.134 & .182 & -.017 & .169 & .233 & .164 & .301 & -.067 & -.045 & 1.000\end{array}$

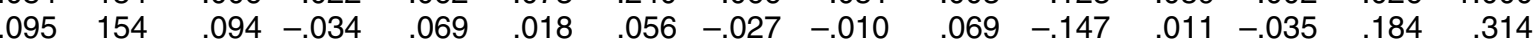

$\begin{array}{llllll}.178 & 154 & -.010 & -.027 & -.047 & -.005\end{array}$

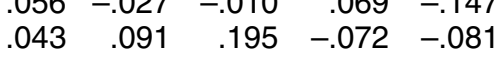

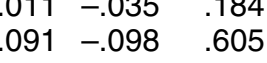

$\begin{array}{llllllll}.486 & & .500 & 108 & -.208 & .007 & -.027 & -.030\end{array}$

$\begin{array}{llll}.014 & -.170 & -.181 & -.108\end{array}$

$.038-.103$

$.102-.428$

Notes: All correlations greater than .05 and less than -.05 are significant at $p<.05$. 
Raudenbush 1992). Table 3 provides detailed findings from the analysis.

Consistent with our conceptual framework, we observed that brand-association trademarks increase cash flows $(\beta=$ 7.820 , $t$-value $=3.58$ ) and decrease cash flow variability $(\beta=-.044$, $\mathrm{t}$-value $=-1.97)$. Moreover, we observed that brand-association trademark activity is positively associated with Tobin's q $(\beta=.007$, $\mathrm{t}$-value $=2.41)$, ROA $(\beta=.051$, $\mathrm{t}$-value $=3.16)$, and stock returns $(\beta=.003$, $\mathrm{t}$-value $=5.01)$. Together, the findings imply that a firm's efforts aimed to establish consumer brand associations enhance its financial value. Next, we found that the interaction between brandidentification and brand-association trademarks was positively associated with cash flows $(\gamma=.019$, t-value $=1.98)$. However, its impact on cash flow variability $(\gamma=.001$, $\mathrm{t}$-value $=.45)$ and $\operatorname{ROA}(\gamma=-.0004$, $\mathrm{t}$-value $=-1.05)$ was not significant. Furthermore, we observed that the interaction term was negatively associated with Tobin's q $(\gamma=$ $-.0001, \mathrm{t}$-value $=-1.96)$ and stock returns $(\gamma=-.0001$, $\mathrm{t}$-value $=-2.02)$. As such, our findings provide mixed effects of brand awareness on firm value. 5

In addition to the effects of primary interest, we observed that prior earnings are positively associated with cash flows $(\beta=.248$, $\mathrm{t}$-value $=16.10)$ and ROA $(\beta=.001$, $\mathrm{t}$-value $=3.27$; , however, prior earnings had a marginally negative effect on stock returns $(\beta=-.001$, $\mathrm{t}$-value $=-1.80)$. Next, with respect to the role of firm characteristics, our analysis revealed that larger firms generated greater cash flows $(\gamma=937.23$, t-value $=4.42)$ and greater $\operatorname{ROA}(\gamma=$ 2.249 , $\mathrm{t}$-value $=2.86$ ). We also found evidence that relative branding efforts, as captured by a firm's trademark intensity, are associated with higher cash flows $(\gamma=978.62$, $\mathrm{t}$-value $=3.85)$ and Tobin's $\mathrm{q}(\gamma=.478$, $\mathrm{t}$-value $=2.97)$. We observed that advertising intensity was marginally negatively associated with ROA $(\gamma=-3.360$, $\mathrm{t}$-value $=-1.83)$. Among industry characteristics, market demand was positively associated with cash flows $(\alpha=1576.49$, $\mathrm{t}$-value $=$ 4.29 ) and stock returns $(\alpha=.231$, t-value $=3.35)$, but its impact was not significant for the other outcome variables. The results also suggest that stock returns were greater in less stable industries $(\alpha=.181$, t-value $=2.52)$. Finally, we found that Tobin's q was marginally greater in servicebased industries than in manufacturing industries $(\alpha=.641$, $\mathrm{t}$-value $=1.85$ ).

\section{Robustness Check}

Model specification. We also estimated alternative models to test the robustness of our model specification. First, instead of distinguishing between brand-identification and brand-association trademarks, we used a composite measure capturing the stock of all live trademarks available to a firm in a given year as our key predictor variable. Comparison of fit indexes of the two approaches supported our model (Equations 3-5) for all five outcome variables. ${ }^{6}$ Second, instead of using the stock of all live trademarks as

\footnotetext{
${ }^{5}$ Following our conceptual framework, we did not evaluate the main effects of brand-identification trademarks in our estimations.

${ }^{6}$ Model comparison details are available from the first author on request.
}

inputs in Equations 3-5, we evaluated a model including only newly registered live association and awareness trademarks in a given year. The significance patterns were robust to this specification as well. However, the use of stock of all trademarks rather than only stock of newly registered live trademarks as inputs provided better fit with the data. Third, we explored whether incorporating more lags in brandidentification and brand-association trademarks provided a better fit. By applying Davidson and MacKinnon's (1981) J-test, we confirmed that including the alternative number of lags does not invalidate our model. Finally, we reestimated our model, including the square of lagged advertising intensity and square of lagged branding efforts, to investigate nonlinear effects (not reported in Table 3). ${ }^{7}$ The parameter estimates for the square of brand-association trademarks in Equation 3 were not significant with respect to all outcome measures except for stock returns, for which the estimate was negative and marginally significant $(p<$ .08 ). The parameter estimates for the square of brandidentification trademarks and the square of advertising intensity $\left(\mathrm{AD}_{\mathrm{ij}}\right)$ in Equation 4 were also nonsignificant. Moreover, inclusion of these terms did not improve the overall model fit or change the significance of other estimates reported in Table 3 . We discuss these findings in detail in the "Implications" section.

Endogeneity. Shugan (2004) suggests that a firm's past performance determines its marketing investments; therefore, successful firms might engage in more trademark registrations. ${ }^{8}$ Consequently, it was critical to test for potential endogeneity in our model specification. Unfortunately, there are no established instruments that adequately capture firms' branding investments. However, on the basis of extant research in this area, we employed two sets of instruments to assess endogeneity in our analysis. First, empirical findings indicate that a firm's number of brands and its sales, general, and administrative expenditures are related to its branding efforts (e.g., Bahadir, Bharadwaj, and Srivastava 2008; Rao, Agarwal, and Dahlhoff 2004). Therefore, we used these as instruments. We also employed the ratio of firm intangible assets to total assets as an additional instrument in this step. The Hausman test failed to reject the null hypothesis of exogeneity for all five outcome variables. Second, following McAlister, Srinivasan, and Kim's (2007) approach, we checked for endogeneity using predicted values of brand-association trademarks, earnings, and brandidentification trademarks, which we obtained from regression of those variables on their respective one-year lagged values as instruments. The results of this variable estimation procedure were consistent with our findings reported in Table 3. The Hausman tests also failed to reject the exogeneity hypothesis for all dependent variables except for cash flows. In addition to instrument variable analysis, we conducted a bivariate Granger causality test to evaluate noncausality among the dependent variables and the measures capturing brand identification and association trade-

\footnotetext{
${ }^{7} \mathrm{We}$ thank an anonymous reviewer for this suggestion.

${ }^{8}$ We thank an anonymous reviewer for this comment.
} 
TABLE 3

Impact of Brand-Identification and Brand-Association Trademarks on Firm Performance and Shareholder Value

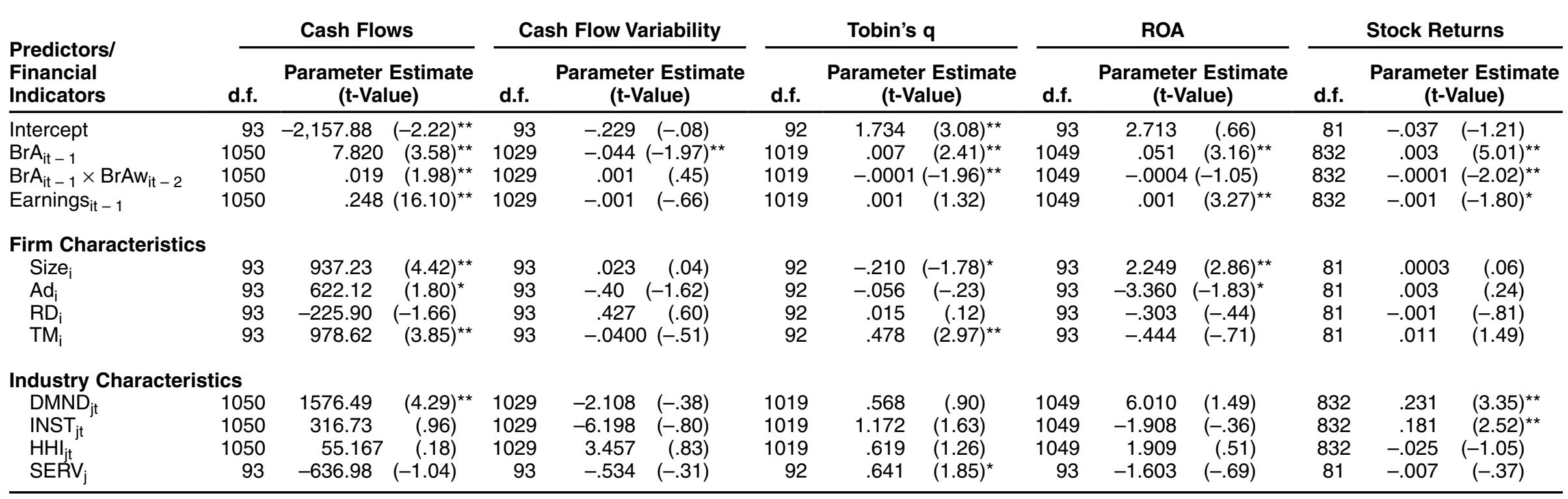

${ }^{*} p<.10$. 
marks. We used one- and two-year lags of the outcome variables for the test (Greene 2003). The test did not support the hypothesis that our outcome measures cause changes in the two types of trademark registrations. Finally, we asked lawyers in our survey to indicate their agreement with the following statement: "Only successful firms engage in trademark registrations." More than $89 \%$ of the respondents disagreed with this statement. On the basis of these observations, we believe that endogeneity does not present a serious problem in our analysis. However, it should be noted that because there are no established instruments that adequately capture firms' branding investments, and given the nature of our data, we cannot completely rule out endogeneity in our analysis.

\section{Discussion and Implications}

Extensive research in marketing has encouraged marketing managers to focus on building brand equity by enhancing consumers' awareness of and associations with brands (Keller 1993). However, the extant literature offers limited insights into the financial returns of such efforts (Keller and Lehmann 2006). The primary focus of our research was to offer a better understanding of the benefits of such a focus.

Specifically, we evaluated the financial value of branding by linking trademark registrations of firms with their financial performance. We broadly classified trademarks into two categories-brand-identification and brandassociation trademarks - and proposed that they are indicators of firms' efforts to build consumer brand awareness and associations, respectively. Our examination of 22,060 trademarks registrations of 108 firms, across multiple industries, and in the period 1995-2005, confirms that efforts aimed to build brand awareness and associations among consumers have significant financial implications for firms. Overall, we observed that brand-association trademarks positively affect firm cash flows, Tobin's q, ROA, and stock returns. Furthermore, brand-association trademarks help reduce the variability of future cash flows. Of particular significance is the observation that, on average, each additional brandassociation trademark is associated with $\$ 7.8$ million of future cash flows, a .05\% increase in future ROA, and a .3\% increase in the future stock returns of a firm. In addition, the findings confirm that by improving consumers' awareness of brands, firms enhance the future cash flows generated by brand associations.

Although we expected a similar positive effect of consumer-brand awareness on stock market measures, our analysis revealed otherwise. We observed that increasing consumer brand awareness diminishes the positive effects of brand-association trademarks on stock returns and Tobin's q. There are two potential explanations for our findings. ${ }^{9}$ First, because it is difficult to find financial and

\footnotetext{
${ }^{9}$ Following the suggestion of an anonymous reviewer, we also evaluated whether the presence of outliers in our data may explain this result. We evaluated the presence of outliers using Cook's distance and restricted likelihood distance parameters. Reestimation of the model without potentially influential observations did not change our results.
}

accounting information for small or newly established firms from secondary databases, we were restricted to relatively large firms with established brands in our sample. Consequently, investors might discount the brand-awareness efforts of such firms.

Second, the investor recognition hypothesis offered in finance literature may also explain our results (Merton 1987). According to that hypothesis, advertising and other marketing efforts that increase a firm's visibility among consumers also attract individual investors to the firm's stocks (Grullon, Kanatas, and Weston 2004; McAlister, Srinivasan, and Kim 2007). It has been documented that individual investors, as opposed to institutional investors, often face cognitive constraints and information collection costs, which restrict their ability to incorporate all relevant information (e.g., changes in cash flows) accurately and instantaneously in their stock valuation (Merton 1987). Consequently, financial models predict that increased individual investor ownership of a firm's stock decreases its short-term stock returns (Merton 1987). Therefore, it is possible that the brand-awareness efforts of firms attract more individual investors to their stocks, thereby attenuating the stock returns and Tobin's q value of such firms. To evaluate this thesis, we obtained stock-ownership information of the firms in our sample from the Thomson Reuters database. Using median split, we classified our sample into two groups (high and low) according to the number of brandidentification trademarks weighted by the number of brands the firms owned. A comparison of the proportion of stocks owned by individual (as opposed to institutional) investors in the two groups demonstrated that the proportion of individual investors owning the stocks was greater for the group of firms with more brand-identification trademarks $(\mathrm{z}=$ $3.01, p<.05)$. Though not conclusive, this observation provides preliminary support for the investor recognition argument.

\section{Research Implications}

By using trademark registration information to capture the financial value of branding, our study makes several contributions to marketing theory. First, it addresses researchers' recent calls to formulate new methodological approaches that bridge the gap between consumer-based and financialmarket-focused perspectives on brand equity (Keller and Lehmann 2006). Extant research focusing on linking consumer-based measures of brand equity with shareholder value has primarily relied on proprietary data (e.g., Mizik and Jacobson 2008; Shankar, Azar, and Fuller 2008), which may not be readily available to many researchers. In contrast, to capture brand equity, we provide a framework that uses trademark registration information, which is objective and easily available to all firms operating in the United States. To the best of our knowledge, our framework is the first to discuss a categorization of trademarks within a branding framework. Future researchers may find our classification approach useful.

Second, extant research on brand valuation has provided rich insights into the financial value of different types of brand associations held by consumers (e.g., Mizik and Jacobson 2008) but has paid limited attention to the role of 
consumer brand awareness in influencing firm financial performance. By confirming that consumer brand awareness influences the financial value of brand associations, our findings may encourage researchers to include brand awareness as an important dimension in models that capture the financial value of branding.

Finally, as mentioned previously, we did not find evidence for quadratic effects of branding efforts and advertising intensity on firms' financial performance. It may be that there is an optimal level of branding and advertising efforts, beyond which such efforts lead to diminishing financial returns. However, McAlister, Srinivasan, and Kim (2007) suggest that firms often lack the appropriate tools to determine the optimal level of marketing spending and thus rarely reach the maximum level of financial performance. This reasoning may potentially explain our findings as well. However, although our analysis gives us confidence in our implications, our findings reflect the marginal effects of branding at the levels represented in our data. Further research might explore other firm and industry contexts for which nonlinear effects can be observed.

\section{Managerial Implications}

This research also offers several important managerial insights. First, our findings should assist marketing managers in more cogently communicating the financial value of branding to management. This becomes especially important during lean economic conditions, when firms may be inclined to make cuts in their brand-related investments. The results imply that such moves may lead to a potential loss of future financial value for firms. Indeed, several instances from business practice also reveal that firms with strong brands, such as McDonald's, are able to raise prices despite a weakening economic environment (Colvin 2009).

Second, scholars have noted that managers rarely work closely with the legal function of their firms (Bosworth 2003). Therefore, it is likely that marketers may not be aware of the many categories of trademarks, such as color, scent, sound, shape, and motion, that have gained legal precedence only recently. We hope that, given the value such trademarks generate, marketers will be motivated to work more closely with their firms' legal counsel.

Finally, this research may motivate firms to review their trademark portfolios more closely to uncover unappreciated trademark opportunities and to benchmark against the best performers. Several examples from industry attest that a forward-looking and well-executed trademark strategy can help build and protect a firm's brand equity. For example, part of Apple's success in building the strong iPod brand has been attributed to its trademark strategy (Orozco and Conley 2008). Apple was proactive in registering the iPod product name, and then it built on that name by registering additional iPod product shape trademarks. The shape trademarks enabled Apple to secure the iPod against competitive threats on its innovative design. On the flip side, under current law, a firm may lose its trademark rights if it no longer uses the trademark in commerce. Some firms have developed businesses that resurrect unused trademarks, which negatively affects the original trademark owner and appropriates any brand equity remaining in the unused trademark. For example, when $\mathrm{P} \& \mathrm{G}$ discontinued its White Cloud brand of toilet tissue, Wal-Mart, in a move unknown to $\mathrm{P} \& \mathrm{G}$, overtook the trademark and adopted it to market its private label of paper goods. Marketers can avoid such potentially damaging trademark strategies of competitors by keeping a close eye on their own activities and on their competitors' trademark activities.

\section{Limitations and Future Research Directions}

Although we offer several important implications, our research suffers from a few limitations that bring to light avenues for future research. First, our sample was restricted to larger firms. This was primarily a result of our focus on the metrics of financial value as dependent variables, for which longitudinal measures are available only for relatively large firms. Further research might include smaller firms with newly established brands to investigate whether the value associated with branding efforts of such firms differs from what we observed in our sample.

Second, we propose that trademarks are measures of firm branding efforts. However, we realize that brandassociation trademarks do not capture all the dimensions of consumer brand associations. For example, as we noted previously, firms are often limited in what they can protect through trademarks. Many aspects of marketing strategy affect a brand's image but cannot be protected through trademarks (e.g., celebrity endorsements, sponsorship events, taste tests). Furthermore, it is not possible to capture the favorability or uniqueness of brand associations through trademarks. Capturing such dimensions likely requires a multimethod approach. In the future, researchers should focus on complementing trademark information with consumer attitudinal information to better capture the financial value of branding.

Finally, analysis that centers on financial performance as the dependent variable and uses secondary measures to capture branding efforts of firms is prone to endogeneity concerns. Although we conducted several tests to ascertain whether endogeneity was a serious concern in our analysis, the lack of established instruments to capture firms' branding investments did not enable us to completely rule out the endogeneity problem. Further research might aim to find better instruments for capturing branding efforts of firms. 
APPENDIX

Trademarks Classification and Examples

\begin{tabular}{|c|c|c|}
\hline \multicolumn{3}{|c|}{ Brand-Identification Trademarks } \\
\hline Category & Example & Owner \\
\hline Word/name (no design) & Coca-Cola & The Coca-Cola Co. \\
\hline Symbol (no wording) & & The Coca-Cola Co. \\
\hline Combination & & The Coca-Cola Co. \\
\hline \multicolumn{3}{|c|}{ Brand-Association Trademarks } \\
\hline Slogan & Just Do It & Nike Corp. \\
\hline $\begin{array}{l}\text { Colors that are part of the physical good } \\
\text { or packaging }\end{array}$ & & McDonald's Corp. \\
\hline Product shapes & & Apple Corp. \\
\hline Packaging & & Procter \& Gamble Co. \\
\hline Sounds & $\begin{array}{l}\text { The mark consists of a five-tone audio } \\
\text { progression of the notes D flat, D flat, G } \\
\text { flat, D flat, and A flat }\end{array}$ & Intel Corp. \\
\hline Scents & $\begin{array}{l}\text { The mark consists of the almond scent } \\
\text { of the goods }\end{array}$ & Manhattan Oil \\
\hline Motion & ity & Yamaha Motor Co. \\
\hline
\end{tabular}

\section{REFERENCES}

Aaker, David A. (1991), Managing Brand Equity: Capitalizing on the Value of a Brand Name. New York: The Free Press.

Ailawadi, Kusum L., Donald R. Lehmann, and Scott A. Neslin (2003), "Revenue Premium as an Outcome Measure of Brand Equity," Journal of Marketing, 67 (October), 1-17.

Bahadir, S. Cem, Sundar G. Bharadwaj, and Rajendra K. Srivastava (2008), "Financial Value of Brands in Mergers and Acquisitions: Is Value in the Eye of the Beholder?" Journal of Marketing, 72 (November), 49-64.

Bennett, Peter D. (1995), Dictionary of Marketing Terms, 2d ed. Chicago: American Marketing Association.

Bosworth, Derek L. (2003), "The Importance of Trademarks to Capital Raising and Financial Performance: Lessons from SMEs," working paper, Manchester School of Management,
University of Manchester Institute of Science and Management.

Bryk, Anthony S. and Stephen W. Raudenbush (1992), Hierarchical Linear Models: Application and Data Analysis Methods. Newbury Park, CA: Sage Publications.

BusinessWeek (2007), "The New Alchemy at Sears," (April 16), (accessed July 8, 2009), [available at http://www.business week.com/magazine/content/07_16/b4030071.htm].

Chung, Kee H. and Stephen W. Pruitt (1994), "A Simple Approximation of Tobin's q," Financial Management, 23 (Autumn), 70-74.

Cohen, Dorothy (1986), “Trademark Strategy,” Journal of Marketing, 50 (January), 61-74. 
Colvin, Geoff (2009), "Yes, You Can Raise Prices," Fortune, 159 (4), 20.

Dacin, Peter A. and Daniel C. Smith (1994), "The Effect of Brand Portfolio Characteristics on Consumer Evaluations of Brand Extensions," Journal of Marketing Research, 31 (May), 229-42.

Davidson, Russell and James G. MacKinnon (1981), "Several Tests for Model Specification in the Presence of Alternative Hypotheses," Econometrica, 49 (May), 781-93.

Davidson, Scott (2004), "When Trademarks, Trade Names, and Brands Get Valued," CA Magazine, 137 (7), 36-38.

Dechow, Patricia M., S.P. Kothari, and Ross L. Watts (1998), "The Relation Between Earnings and Cash Flows," Journal of Accounting and Economics, 25 (2), 133-68.

Erdem, Tulin and Joffre Swait (1998), "Brand Equity as a Signaling Phenomenon," Journal of Consumer Psychology, 7 (2), 131-57.

Fairfield, Patricia M., Richard J. Sweeney, and Teri Lombardi Yohn (1996), "Accounting Classification and the Predictive Content of Earnings," The Accounting Review, 71 (July), 337-55.

Fama, Eugene F. and Kenneth R. French (1993), "Common Risk Factors in the Returns on Stocks and Bonds," Journal of Financial Economics, 33 (February), 3-56.

Greene, William H. (2003), Econometric Analysis, 5th ed. Upper Saddle River, NJ: Pearson Education.

Gruca, Thomas S. and Lopo L. Rego (2005), "Customer Satisfaction, Cash Flow, and Shareholder Value," Journal of Marketing, 69 (July), 115-30.

Grullon, Gustavo, George Kanatas, and James P. Weston (2004), "Advertising, Breadth of Ownership, and Liquidity," Review of Financial Studies, 17 (2), 439-61.

Henderson, Pamela W. and Joseph A. Cote (1998), "Guidelines for Selecting and Modifying Logos," Journal of Marketing, 62 (April), 14-30.

Hofmann, David A. and Mark B. Gavin (1998), "Centering Decisions in Hierarchical Linear Models: Implications for Research in Organizations," Journal of Management, 24 (5), 623-41.

Ismail, Badr and Kwan Choi (1996), "Determinants of Time Series Properties of Earnings and Cash Flows," Review of Financial Economics, 5 (2), 131-45.

Jacoby, Jacob (2001), "The Psychological Foundations of Trademark Law: Secondary Meaning, Genericism, Fame, Confusion and Dilution," Trademark Reporter, 91 (4), 1013-1071.

Keller, Kevin L. (1993), "Conceptualizing, Measuring, and Managing Customer-Based Brand Equity," Journal of Marketing, 57 (January), 1-22.

— and Donald R. Lehmann (2006), "Brands and Branding: Research Findings and Future Priorities," Marketing Science, 25 (6), 740-59.

Kerin, Roger A. and Raj Sethuraman (1998), "Exploring the Brand Value-Shareholder Value Nexus for Consumer Goods Companies," Journal of the Academy of Marketing Science, 26 (4), 260-73.

Krishnan, H.S. (1996), "Characteristics of Memory Associations: A Consumer-Based Brand Equity Perspective," International Journal of Research in Marketing, 13 (4), 389-405.

Lindenberg, Eric B. and Stephen A. Ross (1981), “Tobin's q Ratio and Industrial Organization," Journal of Business, 54 (January), 1-32.

Luo, Xueming (2009), "Quantifying the Long-Term Impact of Negative Word of Mouth on Cash Flows and Stock Prices," Marketing Science, 28 (1), 148-65.

Madden, Thomas J., Frank Fehle, and Susan Fournier (2006), "Brands Matter: An Empirical Demonstration of the Creation of Shareholder Value Through Branding," Journal of the Academy of Marketing Science, 34 (2), 224-35.

Marketing Science Institute-Emory Marketing Institute (2007), "Marketing Strategy Meets Wall Street," (accessed July 8,
2009), [available at http://www.msi.org/research/index.cfm? $\mathrm{id}=146]$.

McAlister, Leigh, Raji Srinivasan, and Min Chung Kim (2007), "Advertising, Research and Development, and Systematic Risk of the Firm," Journal of Marketing, 71 (January), 35-48.

Melton, Carol A. (1979), "Generic Term or Trademark? Confusing Legal Standards and Inadequate Protection," American University Law Review, 29 (1), 109-133.

Merton, Robert C. (1987), "A Simple Model of Capital Market Equilibrium with Incomplete Information," Journal of Finance, 42 (3), 483-510.

Mizik, Natalie and Robert Jacobson (2008), "The Financial Value Impact of Perceptual Brand Attributes," Journal of Marketing Research, 15 (February), 15-32.

Morrin, Maureen, Jonathan Lee, and Greg M. Allenby (2006), "Determinants of Trademark Dilution," Journal of Consumer Research, 33 (September), 248-57.

Nedungadi, Prakash (1990), "Recall and Consumer Consideration Sets: Influencing Choice Without Altering Brand Evaluations," Journal of Consumer Research, 17 (December), 263-76.

Oathout, John D. (1981), Trademarks: A Guide to Selection, Administration, and Protection of Trademarks in Modern Business Practice. New York: Charles Scribner's Sons.

Orozco, David and James G. Conley (2008), "Shape of Things to Come," The Wall Street Journal, (May 12), R6.

Pechmann, Cornelia and S. Ratneshwar (1991), "The Use of Comparative Advertising for Brand Positioning: Association Versus Differentiation," Journal of Consumer Research, 18 (2), $145-60$.

Pham, Michel Tuan and A.V. Muthukrishnan (2002), "Search and Alignment in Judgment Revision: Implications for Brand Positioning," Journal of Marketing Research, 39 (February), 18-30.

Pullig, Chris, Richard G. Netemeyer, and Abhijit Biswas (2006), "Attitude Bias, Confidence, and Challenge Alignment: A Case of Negative Brand Publicity," Journal of the Academy of Marketing Science, 34 (4), 528-42.

Rao, Vithala R., Manoj K. Agarwal, and Denise Dahlhoff (2004), "How Is Manifest Branding Strategy Related to the Intangible Value of a Corporation?" Journal of Marketing, 68 (October), $126-41$.

Rappaport, Alfred (1986), Creating Shareholder Value. New York: The Free Press.

Salinas, Gabriela and Tim Ambler (2008), "A Taxonomy of Brand Valuation Methodologies: How Different Types of Methodologies Can Help to Answer Different Types of Questions," Marketing Science Institute Report No. 08-204.

Shankar, Venkatesh, Pablo Azar, and Matthew Fuller (2008), "BRAN*EQT: A Multicategory Brand Equity Model and Its Application at Allstate," Marketing Science, 27 (July-August), 567-84.

Shugan, Steven M. (2004), "Endogeneity in Marketing Decision Models," Marketing Science, 23 (Winter), 1-3.

Slotegraaf, Rebecca J. and Koen Pauwels (2008), "The Impact of Brand Equity and Innovation on the Long-Term Effectiveness of Promotions," Journal of Marketing Research, 45 (June), 293-306.

Srinivasan, V., Chan S. Park, and Dae R. Chang (2005), "An Approach to the Measurement, Analysis, and Prediction of Brand Equity and Its Sources," Management Science, 51 (9), 1433-48.

Srivastava, Rajendra K., Tasadduq A. Shervani, and Liam Fahey (1999), "Marketing, Business Processes, and Shareholder Value: An Organizationally Embedded View of Marketing Activities and the Discipline of Marketing," Journal of Marketing, 63 (Special Issue), 168-79.

Trademark Act of 1946 (1982), 15 U.S.C. $\$ \S 1051-1127$.

Wyer, Robert S., Jr., and Thomas K. Srull (1989), "Person Memory and Judgment," Psychological Review, 96 (1), 58-83. 
Copyright of Journal of Marketing is the property of American Marketing Association and its content may not be copied or emailed to multiple sites or posted to a listserv without the copyright holder's express written permission. However, users may print, download, or email articles for individual use. 